\title{
Effects of dietary protein level on lactational responses of dairy cows to rumen-protected methionine and lysine
}

\author{
H Rulquin, C Hurtaud, L Delaby
}

INRA, Station de Recherches sur la Vache Laitière, 35590 Saint-Gilles, France

\begin{abstract}
Lactational responses of dairy cows fed maizebased diets to a postruminal supply of lysine and methionine seem to be affected by the CP content of a diet (Rulquin, 1992). However, little directcomparison data is available to support this view.

Therefore, 2 levels of rumen-protected amino acids (RPAA) (providing 0 or $11+30 \mathrm{~g}$ of intestinal absorbable methionine and lysine) were given to dairy cows. The animals were offered 2 diets formulated to cover either $100 \%(13.3 \% \mathrm{CP}$ in DM) or $120 \%(15.1 \%$ CP in DM) of the protein requirements. Sixteen Holstein heifers in their 5 th week of lactation were assigned to a $4 \times 4$ latin square design (4-week periods). The diets contained $70 \%$ maize silage and $30 \%$ concentrate $(75 \%$ energy mix, $14 \%$ soya bean meal, $2 \%$ urea, $4 \%$ minerals and $5 \%$ maize gluten meal 60 ). The high protein diet was formulated by substituting $13 \%$ energy mix ( $30 \%$ dehydrated beet pulps, $25 \%$ barley, $25 \%$ fine wheat bran, $10 \%$ dehydrated alfalfa, $5 \%$ molasses, $1 \%$ fat and $4 \%$ minerals) for the maize gluten meal 60 .
\end{abstract}

Increasing protein allowance significantly improved feed intake and consequently increased milk yield, protein yield and content. RPAA increased only protein yield and content. Milk protein content responses to RPAA tended to be higher on the high than on the low protein diet $(+1.7$ vs $+1.0 \mathrm{~g} / \mathrm{kg} ; P=0.12)$. RPAA increased significantly $(P<0.05)$ fat yield and content on the low CP level but not on the high protein diet. It is expected that the shortage of other limiting amino acids may explain the lower utilisation efficiency of lysine and methionine supplements for milk protein synthesis in cows fed the low protein diet. Therefore the requirements of an individual amino acid cannot be expressed independently of the levels of other amino acids.

Rhône Poulenc Nutrition Animale is gratefully acknowledged for financial support.

Rulquin H (1992) INRA Prod Anim 5, 29-36

Table I. Lactational responses to dietary CP level and rumen-protected methionine and lysine.

\begin{tabular}{|c|c|c|c|c|c|}
\hline & \multicolumn{4}{|c|}{$C P$ diet $(\% D M)$} & \multirow{3}{*}{ SED } \\
\hline & \multicolumn{2}{|c|}{13.3} & \multicolumn{2}{|c|}{15.1} & \\
\hline & 0 & Met + Lys * & 0 & Met + Lys* & \\
\hline Intake (kg DM/d) & $17.6^{a}$ & $18.1^{\mathrm{ab}}$ & $18.3^{b}$ & $18.4^{b}$ & 0.7 \\
\hline Milk yield (kg/d) & $23.6^{a}$ & $23.4^{\mathrm{a}}$ & $24.4^{b}$ & $24.2^{b}$ & 0.8 \\
\hline Fat yield $(\mathrm{g} / \mathrm{d})$ & $998^{a}$ & $1043^{b}$ & $1018^{a b}$ & $1010^{a}$ & 47 \\
\hline Protein yield $(\mathrm{g} / \mathrm{d})$ & $721^{a}$ & $736^{a}$ & $764^{b}$ & $793^{c}$ & 33 \\
\hline Milk fat content $(g / \mathrm{kg})$ & $43.0^{\mathrm{a}}$ & $45.2^{b}$ & $42.2^{\mathrm{a}}$ & $42.6^{a}$ & 1.9 \\
\hline Milk protein content $(\mathrm{g} / \mathrm{kg})$ & $30.8^{a}$ & $31.8^{b}$ & $31.5^{b}$ & $33.2^{c}$ & 0.9 \\
\hline
\end{tabular}

* Rumen-prctected amino acid; a, b, c means in the same line with different superscripts differ significantly at $P<0.05$ 